\title{
Batı Anadolu Fasulye Genetik Kaynaklarının Biyolojik Çeşitliliğinin Araştırılması ve Karakterizasyonu
}

\author{
Huseyin CANCI ${ }^{1}$, Murat BOZKURT ${ }^{2}$, Faik KANTAR ${ }^{3}$, Mehmet Zahit YEKEN ${ }^{4}{ }^{\mathscr{2}}$, Goksel OZER ${ }^{5}$ \\ Vahdettin CIFTCI ${ }^{6}$
}

${ }^{1}$ Akdeniz Üniversitesi, Ziraat Fakültesi, Tarla Bitkileri Bölümü, Antalya, ${ }^{2,3}$ Akdeniz Üniversitesi, Ziraat Fakültesi, Tarımsal Biyoteknoloji Bölümü, Antalya, ${ }^{4,6}$ Bolu Abant İzzet Baysal Üniversitesi, Ziraat ve Doğa Bilimleri Fakültesi, Tarla Bitkileri Bölümü, Bolu, ${ }^{5}$ Bolu Abant İzzet Baysal Üniversitesi, Ziraat ve Doğa Bilimleri Fakültesi, Bitki Koruma Bölümü, Bolu

${ }^{1}$ https://orcid.org/0000-0001-8963-850X, ${ }^{2}$ https://orcid.org/0000-0001-8609-8288, ${ }^{3}$ https://orcid.org/0000-0003-3102-1181,

${ }^{4}$ https://orcid.org/0000-0003-0490-371X, ${ }^{5}$ https://orcid.org/0000-0002-3385-2520, ${ }^{6}$ https://orcid.org/0000-0003-0547-9527

凹: yekenmehmetzahit@gmail.com

\begin{abstract}
ÖZET
Bu çalışmada, Batı Anadolu Bölgesi'nde 10 ilde üretilen 156 önemli yerel fasulye ekotipi 2015 yılında toplanmış ve ekotipler arasındaki biyolojik çeşitliliği araştırmak ve karakterize etmek için 2016 yılında Akdeniz Üniversitesi Ziraat Fakültesi'nde tarla denemesi yürütülmüştür. İncelenen karakterler açısından en belirgin değişim kuru sap ve tane veriminde kaydedilirken bunu bitkide bakla sayısı, baklada tane sayısı, bitki boyu ve yüz tane ağırlığı takip etmiştir. En yüksek bitki başına tane verimi MGL-30 (145.6 g), MGL-38 (101.7 g), ANT-43 (87.8 g) ve MGL-26 (81.9 g) genotiplerinden elde edilmiştir. Temel bileşen analizinde, 17 bileşen yerel fasulye genetik kaynaklarındaki varyasyonun \%74.9'unu izah etmiştir. Bakla rengi, bitki tipi ve sarılma özelliği en fazla katkı sağlayan özellikler olmuştur. Bitki boyu ve olgunlaşma gün sayısı, biplot analizinde tane verimi ile aynı yönde ve en dar açıya sahip vektörler olmuştur. Morfolojik özellikler kullanılarak üretilen benzerlik dendogramı genotipleri iki ana gruba (A ve B) ve dört alt gruba (A1, A2, B1 ve B2 ) ayrılmıştır. Morfolojik özellikler açısından en uzak gruplarda yer alan MGL-01, KTH-01, MNS-01 ve ANT-13 ile UŞK-01, ANT-01, MGL-05 ve AYD-02 ekotipleri kullanılarak melezleme ıslahı ile yeni çeşitler geliştirilebilir.
\end{abstract}

\section{Investigation and Characterization of Phaseolus bean bio-diversity in Western Anatolia}

\section{ABSTRACT}

In this study, 156 important local bean ecotypes produced in 10 provinces in the Western Anatolia Region were collected in 2015, and field trial was conducted in 2016 at Akdeniz University, Faculty of Agriculture in order to investigate and characterize biodiversity. The highest variation was recorded for straw yield and seed yield per plant followed by pod number per plant, seed number per pod, plant height and 100 seed yield. MGL-30 (145.6 g), MGL-38 (101.7 g), ANT-43 (87.8 g) and MGL-26 (81.9 g) gave the highest seed yields per plant. In principle component analysis, 17 components explained $74.9 \%$ of genetic variation in local bean genetic resources. Pod color, plant growth and speed of climbing were the most important traits contributing to diversity. In biplot vector analysis, plant height and days to maturity were of the closest and parallel vector angle to seed yield. Hierarchal constellation cluster analysis on the bases of morphological traits produced two main groups (A and B) and 4 subgroups (A1, A2, B1, and B2). Most distant landraces of MGL-01, KTH01, MNS-01, and ANT-13 to the genotypes of UŞK-01, ANT-01, MGL05 and AYD-02 may be used in a hybridization program.

\section{Araştırma Makalesi}

Makale Tarihçesi

Geliş Tarihi : : 18.06.2019

Kabul Tarihi ：22.08.2019

\section{Anahtar Kelimeler}

Phaseolus sp.,

Morpholojik özellikler,

Yerel ekotipler,

Genetik kaynaklar

$\begin{array}{ll}\text { Article History } & \\ \text { Received } & : 18.06 .2019 \\ \text { Accepted } & : 22.08 .2019\end{array}$

Keywords

Phaseolus sp.,

Morphologic traits,

Landraces,

Germplasm

To Cite : Cancı H, Bozkurt M, Kantar F, Yeken MZ, Özer G, Çiftçi V 2019. Batı Anadolu Fasulye Genetik Kaynaklarının Biyolojik Çeşitliliğinin Araştırılması ve Karakterizasyonu. KSÜ Tarım ve Doğa Derg. 22(Ek Sayı 2): 251-263. DOI: 10.18016/ksutarimdoga.vi.579482 


\section{GİRİş}

Fasulye, dünyada en fazla yetiştirilen yemeklik tane baklagil bitkisidir (Singh et al., 2007). Günümüzde fasulye bitkisinin; Orta Amerika (Mesoamerica) ve Güney Amerika (Andean) bölgeleri olmak üzere iki gen havuzuna sahip olduğu çeşitli araştırıcılar tarafından bildirilmiştir (Blair et al., 2012; Bitocchi et al., 2013). Orta Amerika (Mesoamerica) gen havuzu, Meksika'dan Kolombiya'ya, Güney Amerika (Andean) gen havuzu ise, Güney Peru'dan Kuzeybatı Arjantin'e uzanmaktadır (Kwak et al., 2009; De la Fuente et al., 2012). Durango, Jalisco ve Mesoamerica Orta Amerika gen havuzunda, Peru, Nueva Granada ve Şili Güney Amerika gen havuzunda yer almaktadır (Nadeem et al., 2018). Fasulye, protein, karbonhidrat, lif, vitamin ve mineral maddeler açısından zengin bir besin kaynağıdır (Aquino-Bolaños et al., 2016). 2016 yılı itibariyle dünya üzerinde kuru fasulye ekim alanı 29 $\mathrm{M}$ hektarı geçerken $1.5 \mathrm{M}$ hektar da taze fasulye üretimi yapılmıştır (Anonim, 2018a). Üretim ise sirasiyla kuru fasulyede $26.8 \mathrm{M}$ ton ve taze fasulyede 23.5 M tonu geçmiştir (Anonim, 2018a). Türkiye'de kuru fasulye, nohut ve mercimekten sonra üçüncü sirada bulunmaktadır (Anonim, 2018b). Yine tarla ve sera şartlarında önemli miktarda taze fasulye üretimi bulunmaktadır. 2013 yllında 85.000 ton kuru fasulyenin yanında 632.000 ton taze fasulye üretimi yapılmıştır. Ticari üretimin yanında genellikle kırsal kesimde her hanede küçük bahçe ve tarlada üretim yapılmaktadır. Türkiye çok zengin fasulye genetik çeşitliliğine sahip bulunmaktadır (Elkoca et al., 2010; Khaidizar et al., 2012). Coğrafik çeşitlilik, farklı iklim tipleri ve zengin toprak yapısı yanında farklı tarım teknikleri ve değişen taleplere göre yapılan doğal seleksiyon (Scarano et al., 2014) sonucu Anadolu'da zengin bitki çeşitliliği oluşmuştur. Batı Anadolu Bölgesi'nde birçok üründe yaygınlaşmış yoğun ticari tarımsal uygulamalara rağmen fasulye üretimi esas itibariyle geleneksel yerel tohumlarla yapılmaktadır. Yerel tohumlar üstün lezzetleri ve yüksek adaptasyon yetenekleri dolayısıyla üretici ve tüketiciler tarafından tercih edilmektedir. Bir bölge ve lokasyonda o civara özgü fasulye tipi ve yerel çeşidi bulunmaktadır (İspir fasulyesi, Çandır fasulyesi vb.). Bölgeye özgü yerel tipler tüketici tarafından tercih edildiği için çiftçiler yerel fasulye üretimine devam etmektedir. Ancak, yüksek verimli yeni fasulye çeşitlerinin üretime girmesi, ekim alanlarının azalması ve ithalatın artması yerel fasulye tipleri üzerinde baskı oluşturmaktadır. Yerel tohumların toplanması, karakterizasyonu, muhafazası ve ıslahta kullanılması biyolojik çeşitliliğin korunması için gerekli görülmektedir. Birçok özellik bakımından karakterize edilmiş fasulye genetik kaynakları mevcut ve gelecekte yapılacak ıslah programlarında yüksek adaptasyon yeteneği, üstün kalite özellikleri ve stres faktörlerine toleransa sahip çeşitlerin geliştirilmesi için kullanılabilecektir. Bu çalışma, Batı Anadolu Bölgesi'nde 10 ilde yerel fasulye tohumlarmın toplanması, morfolojik özelliklerinde çeşitliliğin incelenmesi ve yerel tiplerin karakterizasyonu amacıyla yürütülmüştür.

\section{MATERYAL ve YÖNTEM}

\section{Bitki Materyali}

Batı Anadolu Bölgesi'nde bulunan Antalya, Isparta, Burdur, Muğla, Denizli, Aydın, İzmir, Manisa, Uşak ve Kütahya illerinden (Şekil 1) 2015 Ekim ve 2016 Mart aylarinda toplanan 156 yerel fasulye (Phaseolus) gen kaynağı çalışmada materyal olarak kullanılmıştır. Yerel fasulye ekotiplerine toplanıldığ göstermesini kolaylaştırmak amacıyla kod ve numara verilmiştir (Örn. Antalya $=$ ANT, Burdur $=\mathrm{BRD}$, Isparta=ISPT, Denizli=DZL, Muğla=MGL, Aydın=AYD, Izmir=IZM, Manisa=MNS, Uşak=UŞK ve Kütahya=KTH. )

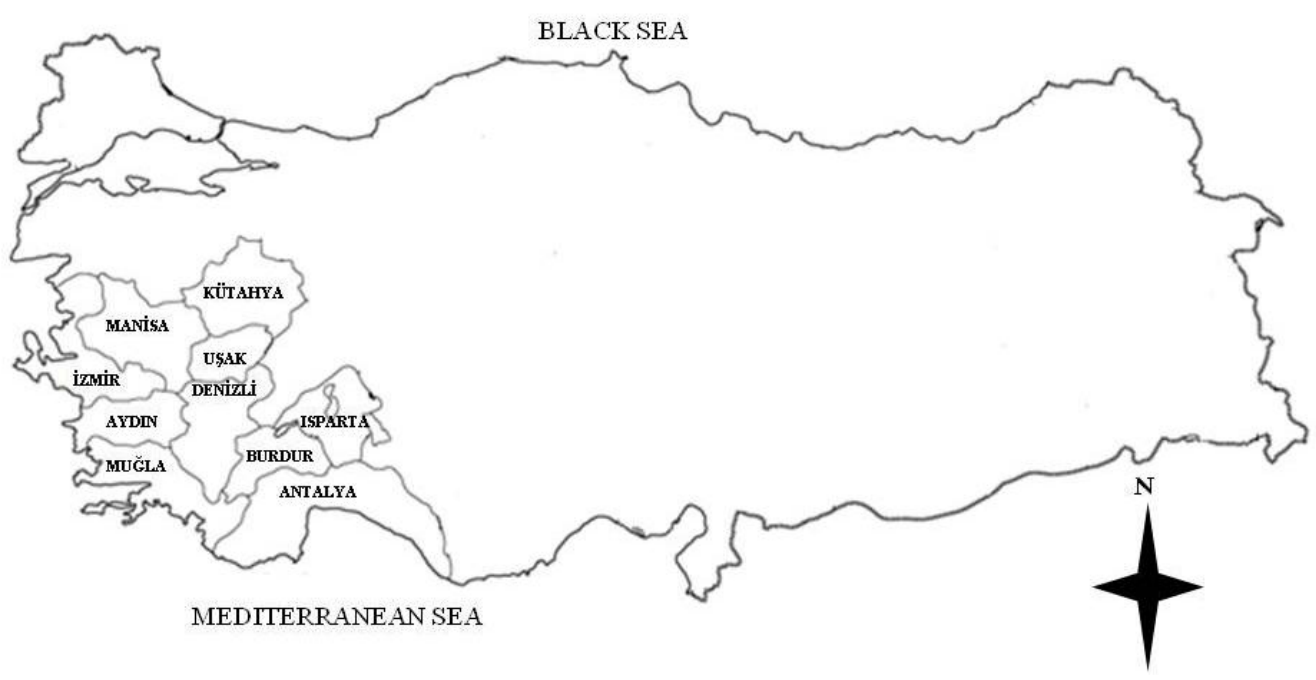

Şekil 1. Yerel fasulye gen kaynaklarının toplandığg bölge ve iller 


\section{Araştırma Sahasının İklim ve Toprak Özellikleri}

Araştırma yerinin denizden yüksekliği yaklaşık $24 \mathrm{~m}$ olup, 3653.933' kuzey enlemi ve $30^{\circ} 38.557^{\prime}$ doğu boylamında yer almaktadır. Denemenin yürütüldüğü aylara ait meteorolojik veriler Çizelge 1' de verilmiştir. Ortalama sıcaklık değerleri uzun yıllar ortalaması ile benzerlik gösterirken, 2016 yılındaki toplam yağış miktarının uzun yıllar ortalamasından oldukça düşük olduğu tespit edilmiştir. Uygulama alanının toprak özellikleri kumlu-killi-tınlı yapıda olup, alkalilik özelliği göstermektedir (pH:7.96). Deneme alanı toprakları organik madde yönünden düşük (\%1.87), alınabilir potasyum (0.61 meq/100 g) bakımından iyi, fosfor bakımından (9.37 ppm) yeterli bulunmuştur. Yapılan analizlerde deneme alanı topraklarının tuz içeriği $0.93 \mathrm{mS} / \mathrm{cm}$ (tuzluluk tehlikesi yok), kireç içeriği ise \%26.5 (aşırı kireçli) olarak tespit edilmiştir (Çizelge 2).

Çizelge 1. Antalya ilinin araştırmanın yürütüldüğü yıl ile uzun yıllar ortalamasına ait bazı iklim verileri.

\begin{tabular}{ccccccc}
\hline & Yll & Nisan & Mayıs & Haziran & Temmuz & Ağustos \\
\hline Ortalama Sıcaklık & 2016 & 19.38 & 20.37 & 26.90 & 29.86 & 30.46 \\
$\left({ }^{\circ} \mathrm{C}\right)$ & $\mathrm{UYO}^{* *}$ & 17.50 & 21.20 & 26.0 & 29.1 & 29.6 \\
\hline \multirow{2}{*}{ Toplam Yağış Miktarı $\left(\mathrm{kg} / \mathrm{m}^{2}\right)$} & 2016 & 0.63 & 0.90 & 0.81 & 0.01 & 0.00 \\
& $\mathrm{UYO}$ & 44.27 & 38.23 & 7.51 & 0.24 & 5.99 \\
\hline Ortalama Nisbi Nem & 2016 & 68.76 & 72.36 & 61.79 & 59.70 & 65.08 \\
$(\%)$ & UYO & 63.9 & 67.9 & 61.0 & 60.2 & 59.8 \\
\hline
\end{tabular}

*T.C. Orman ve Su İşleri Bakanlığı, Devlet Meteoroloji İşleri Genel Müdürlüğü ve Meteoroloji 4. Bölge (Antalya) Müdürlüğü, **UYO: Uzun Yillar Ortalaması

Çizelge 2. Deneme yerinin toprak analiz sonuçları.

\begin{tabular}{lcc} 
Ölçülen Parametreler & Bulunan Değerler & Değerlendirme \\
\hline $\mathrm{pH}$ & 7.96 & Alkali \\
$\mathrm{E} . \mathrm{C}(\mathrm{mS} / \mathrm{cm})$ & 0.93 & Tuzluluk tehlikesi yok \\
$\mathrm{CaCO}_{3}(\%)$ & 26.5 & Aşırı kireçli \\
$\mathrm{Kum}(\%)$ & 45.08 & \\
$\mathrm{Kil}(\%)$ & 31.28 & \\
$\mathrm{Silt}(\%)$ & 23.64 & \\
Bünye & & Kumlu-Killi-Tınlı \\
Organik Madde (\%) & 1.87 & Düsük \\
Toplam N (\%) & 0.10 & Orta \\
$\mathrm{P}(\mathrm{ppm})$ & 9.37 & Yeterli \\
$\mathrm{K}(\mathrm{meq} / 100 \mathrm{~g})$ & 0.61 & İyi \\
$\mathrm{Na}(\mathrm{meq} / 100 \mathrm{~g})$ & 0.15 & Düşük \\
$\mathrm{Ca}(\mathrm{meq} / 100 \mathrm{~g})$ & 37.71 & İyi \\
$\mathrm{Mg}(\mathrm{meq} / 100 \mathrm{~g})$ & 7.12 & İyi \\
$\mathrm{Fe}(\mathrm{ppm})$ & 3.56 & Noksanlık gösterebilir \\
$\mathrm{Zn}(\mathrm{ppm})$ & 0.74 & Noksanlı gösterebilir \\
$\mathrm{Mn}(\mathrm{ppm})$ & 23.15 & Yeterli \\
$\mathrm{Cu}(\mathrm{ppm})$ & 1.36 & Yeterli \\
\hline
\end{tabular}

\section{İncelenen Özellikler}

Araştırmada, Türkiye'nin Batı Anadolu Bölgesi'nden toplanan 156 yerel kuru fasulye genotipi 8 Nisan 2016 tarihinde $2 \mathrm{~m}$ uzunluğundaki sıralara, bodur tiplerde $45 \mathrm{~cm}$ sira arası $10 \mathrm{~cm}$ sira üzeri, sarılıcı tiplerde ise $70 \mathrm{~cm}$ sıra arası $20 \mathrm{~cm}$ sıra üzeri olacak şekilde tek sıra halinde markörle çiziler açılarak elle ekilmiştir. Ekimle birlikte dekara $2.7 \mathrm{~kg}$ azot ve $6.9 \mathrm{~kg}$ fosfor dozlarında Diamonyum Fosfat (DAP) formunda gübre verilmiştir. Bitki gelişme mevsimi boyunca ihtiyaca göre yağmurlama sulama ve insektisit uygulaması yapılmıştır. Yabancı ot mücadelesi elle yolunarak yapılmıştır. Bitki gelişme dönemi süresince her sıradan seçilen 5 temsili bitki üzerinde IPGRI (International Plant Genetic Resources Institute) and
EU-CPVO (European Union Community Plant Variety Office) tarafından belirlenen ve Çizelge'3 de verilen gözlem ve ölçümler yapılmıştır.

\section{İstatistik Analizler}

Temel istatistik analizler ve korelasyon Minitab version 17 istatistik programı kullanılarak yapılmıştır. Temel Bileşen Analizi XLSTAT software (2016.2 version) programı ile yapılmıştır. Eigen değeri $>1$ olan bileşenler analize dahil edilmiştir. İncelenen karakterlerin dağılımı ve ekotiplerin dağılımı ilk iki bileşen kullanılarak görsel hale getirilmiştir. Ekotiplere ait benzerlik takımyıldızı grafiği JMP 13.2.0 istatistik programı kullanılarak oluşturulmuştur. 


\section{BULGULAR ve TARTIŞMA}

156 yerel fasulye ekotiplerini üzerine yapilan bu çalışma incelenen genetik kaynağı içinde nitel (görselkalitatif) ve nicel (ölçülebilir-kantitatif) özellikler açısından önemli oranda varyasyon bulunduğunu göstermiştir (Çizelge 3). Fide, yaprak, sap, çiçek ve bakla gibi görsel olarak değerlendirilen morfolojik özellikler ilgili skala değerine göre değişim göstermiştir (Çizelge 3). Ölçülebilir (kantitatif) değerler açısından da ekotipler arasında önemli oranda varyasyon tespit edilmiştir(Çizelge 3). Salkımda çiçek tomurcuğu sayısı 1-14, çıkış $\% 10^{-0} \%$ 100, çiçeklenme gün sayısı 38-59 gün, bitki boyu 33.8$340.0 \mathrm{~cm}$, bitkide bakla sayıs 5-65 adet, yüz tane ağırlığ 12.4-79.4 g, bitki başına tane verimi 7.1-145.6 $\mathrm{g}$, bitki başına kuru sap verimi 10.6-680.3 g, olgunlaşma süresi 50.0-168.0 gün ve baklada tane sayısı 3-9 adet arasında değişim göstermiştir (Çizelge 3). En yüksek değişim kuru sap ve tane veriminde kaydedilirken bunu bitkide bakla sayısı, baklada tane sayısı, bitki boyu ve yüz tane ağırlığı takip etmiştir (Şekil 2, Çizelge 3).

Verim ve bazı önemli verim unsurları açısından genotip ortalama değerlerinde kaydedilen değişim Şekil 2'de görülmektedir. Bitki boyu 10 misli değişim göstermiştir (33.8-340.0 cm, ortalama $158.8 \mathrm{~cm}$ (Std. sapma $=79.02)$ ). Bitki başına bakla sayısı 10 katı değişim göstermiştir (Ortalama=22.4 adet, St. sapma 12.13). Olgunlaşma gün sayısı 3 katı değişim göstermiştir (Ortalama $=135.5$, Std. sapma=27.97). Yüz tane ağırlığı ise $12.44 \mathrm{~g}$ ile $79.35 \mathrm{~g}$ arasinda değişmiş ve ortalama $33.53 \mathrm{~g}($ Std. sapma $=11.73)$ olmuştur. PKS-01 (79.4 g), ANT-42 (71.9 g), ANT-07 (68.0 g), KTH-18 (64.1 g), MGL-10 (60.1 g), BRD-03 $(55.3 \mathrm{~g})$ ve AYD-16(54.5 g) en yüksek yüz tane ağırlığına sahip genotipler, ANT-24 (17.9 g), ANT-15 (17.8 g), ANT-13 (17.6 g), ANT-21 (16.4 g), ANT-44 (16.1 g), MGL-01 (13.4 g) ve MGL-32 (12.4 g) ise en düşük yüz tane ağırlığına sahip genotipler olarak kaydedilmiştir. Ortalama yüz tane ağırlığı $33.5 \mathrm{~g}$ olmuştur. Bitki başına tane verimi ortalama $30.04 \mathrm{~g}$ (Std. sapma=18.91) olup 6.38 katı değişim göstermiştir (7.1-145.6 g). MGL-30 (145.6 g), MGL-38 (101.7 g), ANT-43 (87.8 g) ve MGL-26 (81.9 g) genotipleri en yüksek verime sahip olurken diğer genotiplerin ortalama tane verimi $72 \mathrm{~g}$ bitki ${ }^{-1}$ altında gerçekleşmiştir. Bitki boyu $100 \mathrm{~cm}$ 'nin altında bulunan 43 bodur fasulye genotipinin tane verimi ortalaması $22.9 \mathrm{~g}$ olarak hesaplanmıştır. Bodur gelişme formuna sahip KTH-04 (69.3 g), KTH-31 (38.5 g), BRD-24 (38.0 g), AYD-06 (37.5 g) ve KTH-29 (35.4 g) en yüksek tane verimi üreten genotipler olarak ortaya çıkmıştır.

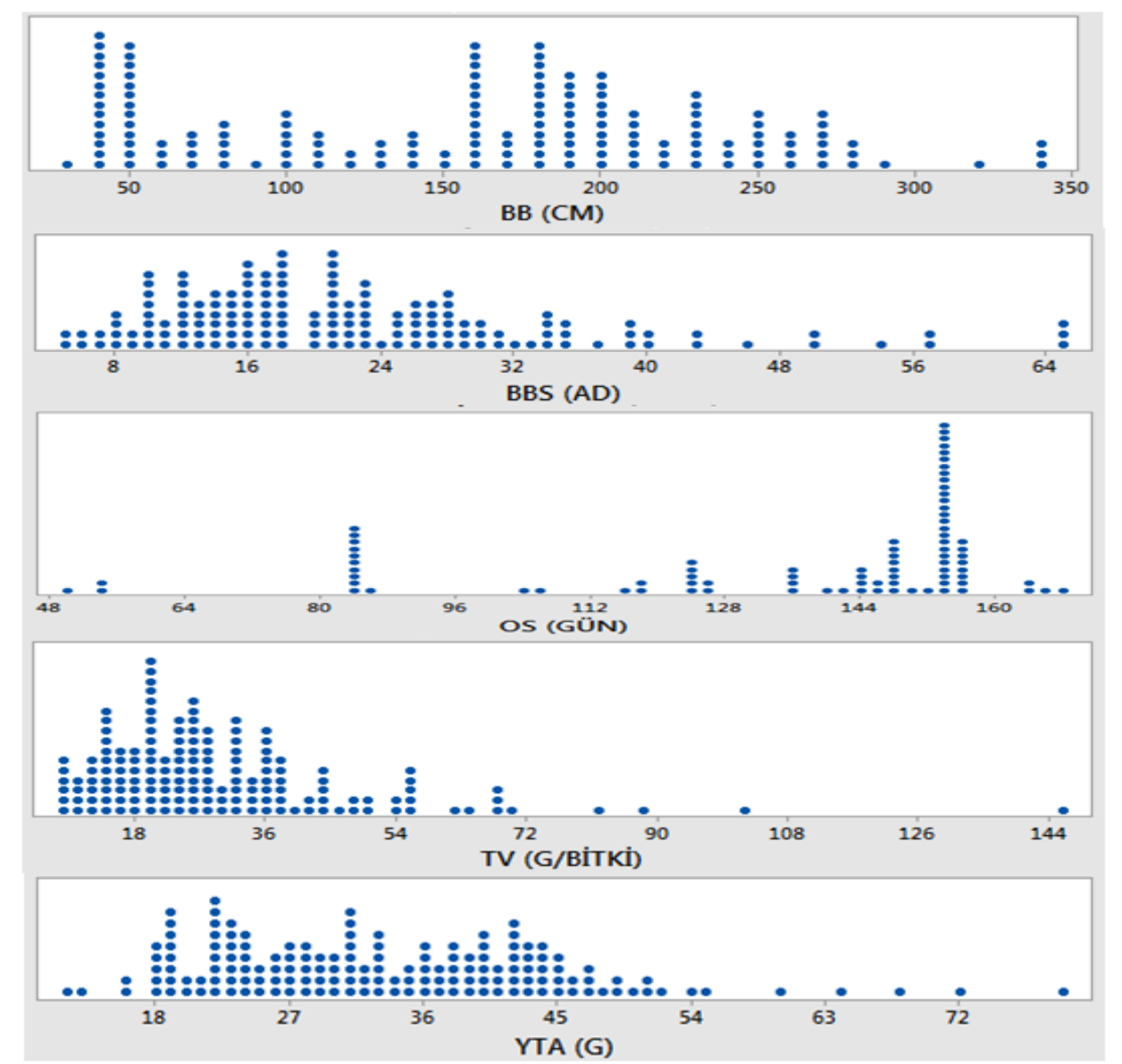

Şekil 2. Yerel fasulye genetik kaynakları içinde bitki boyu (BB), bitki başına bakla sayısı (BBS), olgunlaşma süresi (OS), yüz tane ağırlı̆̆ı (YTA) ve bitki başına tane verimi (TV) değerlerinin değişimi. 
Çizelge 3. Batı Anadolu Bölgesi’nde 10 ilden toplanılan 156 fasulye ekotipi üzerinde tarla şartlarında yapılan gözlem ve ölçümler

\begin{tabular}{|c|c|c|c|}
\hline Özellik (Kısaltma) & Min.-Maks. & Özellik (Kısaltma) & Min.-Maks. \\
\hline Bitki Tipi: Sarılıcı 0 - Bodur 1 (S-B) & $0-1$ & $\begin{array}{l}\text { 2.Rengin yoğunluğu ( } 3=\text { Zayıf, } 5=\text { Orta, } 7= \\
\text { Yoğun) (2.R.K.) }\end{array}$ & 3-7 \\
\hline Fide Antosiyanin (1=Yok, 9=Var) (A) & $1-9$ & $\begin{array}{l}\text { Olgunlaşmamış Tanenin Kabuk Rengi (1= } \\
\text { Beyaz, } 2=\text { Yeşil) (OTKR) }\end{array}$ & $1-2$ \\
\hline $\begin{array}{l}\text { Sarılma Başlangıcı (3=Erken, 5=Orta, 7=Geç) } \\
\text { (SB) }\end{array}$ & $3-7$ & Kılçıklılık (1=Yok, 9= Var) (K) & $1-9$ \\
\hline Sarılma Hızı ( $3=$ =avaş, 5=Orta, $7=$ Hızlı) (SH) & 3-7 & $\begin{array}{l}\text { Bakla Kesit Şekli (1=Eliptik, } 2=\text { Cordate, } 3= \\
\text { Dairesel, } 4=8 \text { şekilli) (BKŞ) }\end{array}$ & $1-3$ \\
\hline Sarılma Gücü ( $3=\mathrm{Az}, 5=$ Orta, $7=$ Güçlü) (SG) & $3-7$ & $\begin{array}{l}\text { Baklanın Bitkideki Durumu (Bodur Tiplerde) } \\
\text { (1=Altta, } 2=\text { Ortada, 3=Üstte, } 4=\text { Uçta, } \\
\text { 5=Diğer) (BBD) }\end{array}$ & $2-3$ \\
\hline $\begin{array}{l}\text { Sarılma Eğilimi ( } 3=\text { Erken, 5=Orta, 7=Geç) } \\
\text { (SE) }\end{array}$ & $3-7$ & $\begin{array}{l}\text { Bakla Ucunun Gaga Uzunluğu (1=Çok kısa, } \\
3=\text { Kısa, 5=Orta, } 7=\text { Uzun, 9=Çok uzun) (BUGU) }\end{array}$ & $1-9$ \\
\hline $\begin{array}{l}\text { Yaprak Rengi (1=Çok açık yeşil, 3=Açık yeşil, } \\
5=\text { Orta yeşil, } 7=\text { Koyu yeşil, 9=Çok koyu yeşil) } \\
\text { (YR) }\end{array}$ & $1-9$ & $\begin{array}{l}\text { Bakla Genişliği (3= Dar, 5= Orta, 7= Geniş) } \\
\text { (BG) }\end{array}$ & $3-7$ \\
\hline Pürüzlülük (3= Zayıf, 5= Orta, 7= Fazla) (P) & 3-7 & $\begin{array}{l}\text { Gaganın Kıvrılması (1=Çok güçsüz, 3=Güçsüz, } \\
5=\text { Orta, } 7=\text { Güçlü, } 9=\text { Çok güçlü) }(\mathrm{GK})\end{array}$ & $1-9$ \\
\hline $\begin{array}{l}\text { Orta Yaprakçı̆ğın Büyüklüğü (3=Küçük, } \\
5=\text { Orta, } 7=\text { Büyük) (OYP) }\end{array}$ & $3-7$ & $\begin{array}{l}\text { Bakla Yüzeyinin Yapısı ( } 3=\text { Düz, } 5=\text { Orta, } 7= \\
\text { Kıvrık) (BYY) }\end{array}$ & $3-5$ \\
\hline $\begin{array}{l}\text { Orta Yaprakçığın Şekli (1=Üç köşeli, 2=Üç } \\
\text { köşeliden dairesele, 3=Dairesel, 4=Daireselden } \\
\text { köşeliye, 5=Köşeli) (OYş) }\end{array}$ & $1-5$ & $\begin{array}{l}\text { Gaganın Oluşum Şekli (1=Güçlü, 2=Orta, } \\
3=\text { Güçsüz) (GOŞ) }\end{array}$ & $1-3$ \\
\hline $\begin{array}{l}\text { Orta Yaprakçı̆̆ın Uç Şekli (3=Kısa, 5= Orta, } \\
7=\text { Uzun) (OYUŞ) }\end{array}$ & $3-7$ & $\begin{array}{l}\text { Gaganın Uzunluğu (3=Kısa, 5= Orta, 7=Uzun) } \\
\text { (GU) }\end{array}$ & $3-7$ \\
\hline $\begin{array}{l}\text { Brakte Boyutu (3=Küçük, 5= Orta, 7=Büyük) } \\
\text { (BB) }\end{array}$ & $3-7$ & $\begin{array}{l}\text { Baklanın Kıvrım Şekli (1= Düz, 3=Hafif, } \\
\text { 5=Orta, 7=Kuvvetli, 9=Çok kuvvetli) (BKŞ) }\end{array}$ & $1-9$ \\
\hline $\begin{array}{l}\text { Brakte Rengi (1=Yeşil, 2=Açık mor, 3=Koyu } \\
\text { mor, 4=Diğer) (BR) }\end{array}$ & $1-2$ & $\begin{array}{l}\text { Bakla Kıvrımının İç bükey Dış bükey Oluşu } \\
\text { (1= İç bükey, 2=Güçlü, 3=Dış bükey) } \\
\text { (BKIDBO) }\end{array}$ & $1-3$ \\
\hline Brakte Şekli (1=Mızrak, 3= Orta, $5=$ Oval) (BŞ) & $1-5$ & Çıkış (\%) (ÇKŞ) & $10-100$ \\
\hline $\begin{array}{l}\text { Bayrak Yaprak Rengi (1= Beyaz, 2=Pembe, } \\
\text { 3=Menekşe, 4=Yeşil) (BYR) }\end{array}$ & $1-3$ & Çiçeklenme Gün Sayısı (Gün) (ÇGS) & $38-59$ \\
\hline $\begin{array}{l}\text { Kanatçık Rengi (1=Beyaz, 2= Pembe, 3= Mor) } \\
\text { (KR) }\end{array}$ & $1-3$ & Bakla Bağlama Gün Sayısı (Gün) (BBGS) & $43-63$ \\
\hline $\begin{array}{l}\text { Kanatçıkların Açılım Durumu (3=Birbirine } \\
\text { Paralel, 5=Birbirinden Ayrılmış, 7=Birbirinden } \\
\text { Iyice Ayrılmış) (KAD) }\end{array}$ & $3-7$ & Bitkide Dal Sayısı (Adet) (BDS) & $3.0-9.6$ \\
\hline $\begin{array}{l}\text { Bodur Tiplerde Çiçeğin Bitkide Bulunduğu Yer } \\
\text { (1= Yaprak İçinde, 2=Yaprak Kısmında, } \\
\text { 3=Yaprak üzerinde) (BTÇBBY) }\end{array}$ & $1-1$ & İlk Bakla Yüksekliği (cm) (IBY) & $7-38$ \\
\hline Çiçek Uzunluğu (mm) (ÇU) & $10.2-41.3$ & Bitki Boyu $(\mathrm{cm})(\mathrm{BB})$ & $33.8-340.0$ \\
\hline Çiçek Sapı Uzunluğu (mm) (ÇSU) & $5.3-38.4$ & Bitkide Bakla Sayısı (Adet) (BBS) & $5-65$ \\
\hline $\begin{array}{l}\text { Çiçek Boyutu ( } 3=\text { Küçük, 5=Orta, 7=Büyük) } \\
\text { (ÇB) }\end{array}$ & 3-7 & Yüz Tane Ağırlığı (g) (YTA) & $12.4-79.4$ \\
\hline İlk Çiçek Boğum Sayısı (adet) (IÇBS) & $2-7$ & Tane Verimi (g/bitki) (TV) & $7.1-145.6$ \\
\hline $\begin{array}{l}\text { Salkımda Çiçek Tomurcuğu Sayısı (adet) } \\
\text { (SÇTS) }\end{array}$ & $1-14$ & Olgunlaşma Süresi (Gün) (OS) & $50.0-168.0$ \\
\hline $\begin{array}{l}\text { Baklanın Koyuluğu (3= Hafif, } 5=\text { Orta, } 7= \\
\text { Koyu) (BK) }\end{array}$ & $3-7$ & Kuru Sap Verimi (g/bitki) (KSV) & $10.5-680.3$ \\
\hline Baklada Çift Renk (1= Yok, 9= Var) (BÇR) & 1-9 & Baklada Tane Sayısı (Adet) (BTS) & $3-9$ \\
\hline $\begin{array}{l}\text { Bakla Kabuğunda 2.RENK (1= Kırmızı, } 2= \\
\text { Mor) (BK 2.RENK) }\end{array}$ & $1-2$ & Tane Dökme(0=Yok, 1=Var) (TD) & $0-1$ \\
\hline
\end{tabular}

Toplam sayısı 113 olan sarılıcı genotiplerin (bitki boyu $>100 \mathrm{~cm}$ ) bitki başına tane verimi ortalama $32.8 \mathrm{~g}$ olarak hesaplanmıştır. Sarılıcı bitki gelişme özelliğine sahip MGL-30 (145.6 g), MGL-38 (101.7 g), ANT-43 (87.8 g), MGL-26 (81.9 g) ve ANT-29 (68.75) en yüksek dane verimine sahip genotiplerdir. Bodur tipler içinde en yüksek tane verimine sahip KTH-04 (69.3 g), KTH31 (38.5 g), BRD-24 (38.0 g), AYD-06 (37.5 g), KTH-29 (35. $4 \mathrm{~g}$ ) ve MNS-05 (35.2 g) en yüksek verime sahip olmuştur. 
Verim ve önemli verim unsurları arasında hesaplanan korelasyon katsayıları incelendiğinde (Çizelge 4) tane verimi, bitki başına bakla sayısı ile önemli oranda ilişkili $(\mathrm{r}=0.545, \mathrm{P}<0.01)$ bulunurken kuru sap verimi bitki boyu ile $(\mathrm{r}=0.521, \mathrm{P}<0.01)$ ilişkili bulunmuştur. Tane verimi ile kuru sap verimi arasındaki ilişki önemli, fakat düşük korelasyon katsayısı değerine $(\mathrm{r}=0.371, \mathrm{P}<0.01)$ sahip olmuştur. Diğer verim ve evrim unsurları arasinda tespit edilen korelasyon katsayıları genellikle düşük $(r<0.6)$ bulunmuştur (Çizelge 4).

Genetik kaynaklara ait incelenen karakterler üzerinde temel bileşen analizi yapılmıştır. Yerel fasulye genetik kaynakları temel bileşen analizinde 17 bileşen 1> eigen değerleri vermiştir (Çizelge 5). Eigen değeri 1 ve üzeri olan 17 bileşen varyasyonun \%74.9'unu izah etmiştir (Çizelge 5). En yüksek Eigen değerleri surasiyla $8.50,4.48$ ve 2.98 ile F1, F2 ve F3 bileşenlerinden elde edilmiştir (Çizelge 5). En yüksek Eigen değerine sahip 5 bileşen Çizelge 6 'da verilmiştir. F1 ekseninde en yüksek değerler bitki tipi (S-B) (0.94), BTÇBBY (0.94), BBD (0.93), sarılma hızı (SH) (-0.90), sarılma gücü (SG) (-0.90), sarılma eğilimi (SE) (-0.76) ve sarılma başlangıcı (SB) (-0.75) özelliklerine ait olmuştur. F1 ekseni bitki tipi ve sarılma özelliklerini açıklamakta olup 8.50 ile en yüksek Eigen değerini vermiştir (Çizelge 6). Fasulye genotiplerinde ölçülen morfolojik özellikler bakımından varyasyona en yüksek katkıyı, bitki tipi, sarılma ve ilk fide gelişmesine ait değerler vermiştir (Çizelge 6). İkinci en yüksek Eigen değerine sahip bileşen olan F2 ekseninde ise bayrak yaprak rengi (BYR) (0.66), kanatçık rengi (KR), (0.65), baklada çift renk (BÇR) (0.77), bakla kabuğunda 2.renk (0.77) ve 2.rengin yoğunluğu (0.73) en yüksek değerlere sahip olmuştur (Çizelge 6). Fasulye genetik kaynaklarına ait morfolojik özellikler içinde çiçek ve bakla rengi, varyasyona en fazla katkı sağlayan ikinci önemli özellikler olarak ortaya çıkmıştır. Baklada çift renk (BÇR) (0.45), bakla kabuğunda 2.renk (0.43), 2.rengin yoğunluğu (0.42), bakla ucunun gaga uzunluğu (BUGU) (0.50) ve bakla genişliği (BG) (-0.45) özellikleri aynı zamanda F3 ekseninde en yüksek Eigen değerini veren (2.98) bileşenler olarak ortaya çıkmıştır. Bakla rengi ve bakla özellikleri varyasyona üçüncü derecede katkı sağlayan özellikler olmuştur (Çizelge 6). F4 ekseninde olgunlaşmamış tanenin kabuk rengi (OTKR) (-0.44) ve kılçıklılık (K) (0.57) ve F5 ekseninde çiçek uzunluğu (ÇU) (0.62), çiçek sapı uzunluğu (ÇSU) (0.49), SÇTS $(0,43)$, BYY $(0,42)$, TD $(0,41)$ ve çiçek boyu (ÇB) $(0.40)$ sirasiyla 4 . ve 5 . en yüksek Eigen değerlerine sahip bileşenlerdir (Çizelge 6). İncelen temel bileşenlerin kısmi katkıları Şekil 2'de verilmiştir. İkinci bileşene ait baklada çift renk (BÇR), bakla kabuğunda 2.Renk (BK 2. Renk) ve baklada ikinci renk (2. Renk) en yüksek kısmi katkı değeri (11.0-12.5) verirken bunu I. temel bileşeni oluşturan bitki tipi (sarılıcı-bodur) (S-B), sarılma başlangıcı (SB), sarılma hızı (SH), sarılma gücü (SG), sarılma eğilimi (SE), bodur tiplerde çiçeğin bitkide bulunduğu yer (BTÇBBY), baklanın bitkideki durumu (bodur tiplerde) (BBD) ve bitki boyu (BB) özelliklerine ait katkı değerleri takip etmiştir (Şekil 3). İkinci temel bileşenleri BYR ve KR katkısı yine I. temel bileşen faktörlerine yakın olmuştur (Şekil 3). III. temel bileşenlerinden Bakla ucunun gaga uzunluğu (BUGU), bakla genişliği (BG), gaganın kıvrılması (GK), İlk çiçek boğum sayısı (İÇBS), gaganın oluşum şekli (GOŞ), ilk bakla yüksekliği (İBY) ve Gaga Uzunluğu (GU) azalan oranlarda 7.5 ile 5.0 arasında kısmi katkı değerlerine sahip olmuştur (Şekil 3). İncelenen morfolojik ve fenolojik karakterlerin vektör uzunlukları ve tane verimi dahil karşılıklı ilişkilerini gösteren Biplot grafiği Şekil 4'te verilmiştir. Bodur tiplerde çiçeğin bitkide bulunduğu yer (BTÇBBY), baklanın bitkideki durumu (bodur tiplerde) (BBD), bitki tipi (sarılıcı-bodur) (S-B), kuru sap verimi (KSV) , bakla Kabuğunda 2.renk (BK 2.RENK), 2.Rengin yoğunluğu (2.R.K.), sarılma eğilimi (SE) ve sarılma başlangıcı (SB) en yüksek vektör uzunluklarına sahip olmuştur (Şekil 4). Bitki boyu (cm), olgunlaşma gün sayısı (OG), çiçek sapı uzunluğu (ÇSU), çiçek boyutu (ÇB), ilk çiçek boğum sayısı (İÇBS), orta yaprakçığın büyüklüğü (OYB) ve ilk bakla yüksekliği (İBY) özellikleri tane verimi ile aynı yönde ve en dar açıya sahip vektör değerlerine sahip özellikler olarak ortaya çıkmıştır (Şekil 4). Bakla ucunun gaga uzunluğu (BUGU), gaga uzunluğu (GU),gaganın oluşum şekli (GOŞ), baklanın kıvrım şekli (BKŞ), baklada kılçıklılık (K), bakla kesit şekli (BKŞ) ve yaprak rengi (YR) özellikleri tane verimine en geniş açılı ve zıt yönde vektörler olarak ortaya çıkmıştır (Şekil 4). Erken sarılma başlangıcı $(\mathrm{SB}=3)$, hızlı sarılma $(\mathrm{SH}=7)$, güçlü sarılma $(\mathrm{SG}=7)$ ve erken sarılma eğilimi $(\mathrm{SE}=3)$ özellikleri ölçü olarak alındığında bitki boyu $129.6 \mathrm{~cm}$ ile $340 \mathrm{~cm}$ boya sahip sarılıcı 22 genotip öne çıkmaktadır (Çizelge 7). 22 genotipten ANT-43 (87.8 g), MGL-18 (68.4 g), DZL-09 (56.2 g), MGL-24 (49.0 g) ve PKS-01 (36.3 g) en yüksek tane verimine sahip olmuştur (Ort. 29.8 g) (Çizelge 7). Bayrak Yaprak Rengi (BYR) özelliği Baklada Çift Renk (BÇR) $(\mathrm{r}=0.414, \mathrm{P}<0.01)$, Bakla Kabuğunda 2.Renk (BK 2.RENK) ( $\mathrm{r}=0.397, \mathrm{P}<0.01)$, 2.Rengin yoğunluğu (2 R.K) $\quad(\mathrm{r}=0.381, \quad \mathrm{P}<0.01)$, Olgunlaşmamış Tanenin Kabuk Rengi (OTKR) $(\mathrm{r}=0.189, \mathrm{P}<0.05)$ ve Kılçılklılık (K) $(\mathrm{r}=0.420, \mathrm{P}<0.01)$ özelliği ile ilişkili bulunmuştur.

Ayrıca, Kanatçık Rengi (KR) özelliği Baklada Çift Renk (BÇR) $(\mathrm{r}=0.414, \mathrm{P}<0.01)$, Bakla Kabuğunda 2.Renk (BK 2.RENK) $(\mathrm{r}=0.397, \quad \mathrm{P}<0.01), 2$. Rengin yoğunluğu (2 R.K) $(r=0.381, P<0.019)$, Olgunlaşmamış Tanenin Kabuk Rengi (OTKR) $(r=0.219, \mathrm{P}<0.05)$ ve Kılçıklılık (K) $(\mathrm{r}=-0.420, \mathrm{P}<0.01)$ özelliği ile ilişkili bulunmuştur. 
Çizelge 4. Batı Anadolu Fasulye Genetik Kaynakları Verim ve Verim Bileşenleri Arasındaki korelasyon katsayıları

\begin{tabular}{|c|c|c|c|c|c|c|c|c|c|c|c|}
\hline & ÇGS & BBGS & BDS & İBY & BB & BBS & YTA & TV & OS & KSV & BTS \\
\hline ÇKŞ\% & -0.018 & -0.014 & -0.118 & 0.127 & 0.005 & 0.061 & 0.120 & $0.206^{* *}$ & 0.054 & 0.059 & -0.086 \\
\hline ÇGS(gün) & 1 & $0.987 * *$ & 0.137 & 0.042 & $0.305^{* *}$ & $0.165^{*}$ & $-0.357 * *$ & 0.031 & $0.202^{*}$ & $0.276^{* *}$ & $0.283^{* *}$ \\
\hline BBGS(gün) & & 1 & 0.129 & 0.026 & $0.309 * *$ & $0.162^{*}$ & $-0.364 * *$ & 0.039 & $0.192^{*}$ & $0.279 * *$ & $0.302^{* *}$ \\
\hline BDS(adet) & & & 1 & 0.002 & 0.078 & 0.043 & -0.137 & 0.016 & 0.058 & $0.204^{*}$ & 0.024 \\
\hline İBY(cm) & & & & 1 & 0.121 & 0.003 & 0.066 & 0.034 & 0.118 & 0.062 & 0.142 \\
\hline $\mathrm{BB}(\mathrm{cm})$ & & & & & 1 & 0.121 & -0.041 & $0.179 *$ & $0.283^{* *}$ & $0.521 * *$ & 0.15 \\
\hline BBS(adet) & & & & & & 1 & $-0.32^{* *}$ & $0.545^{* *}$ & $0.226^{* *}$ & $0.252^{* *}$ & $0.219 * *$ \\
\hline YTA (g) & & & & & & & 1 & -0.038 & -0.118 & -0.01 & $-0.224^{* *}$ \\
\hline TV(g bitki $\left.{ }^{-1}\right)$ & & & & & & & & 1 & $0.235^{* *}$ & $0.371^{* *}$ & $0.192^{*}$ \\
\hline OS(gün) & & & & & & & & & 1 & $0.26^{* *}$ & 0.083 \\
\hline KSV(g bitki-1) & & & & & & & & & & 1 & $0.159^{*}$ \\
\hline BTS(adet) & & & & & & & & & & & 1 \\
\hline
\end{tabular}

${ }^{*} \mathrm{P}<\% 0.05$ seviyesinde önemli, ${ }^{* *} \mathrm{P}<0.01$ seviyesinde önemli

Çizelge 5. Yerel Fasulye genetik kaynakları temel bileşen analizine ait eigen değerleri, yüzde varyasyon ve kümilatif değerleri

\begin{tabular}{|c|c|c|c|c|c|c|c|c|c|c|c|c|c|c|c|c|c|}
\hline & F1 & F2 & F3 & F4 & F5 & F6 & F7 & F8 & F9 & F10 & F11 & F12 & F13 & F14 & F15 & F16 & F17 \\
\hline Eigen değeri & 8.50 & 4.48 & 2.98 & 2.67 & 2.52 & 2.13 & 2.03 & 1.88 & 1.71 & 1.56 & 1.42 & 1.36 & 1.29 & 1.19 & 1.15 & 1.09 & 1.03 \\
\hline Varyasyon (\%) & 16.3 & 8.6 & 5.7 & 5.1 & 4.8 & 4.0 & 3.9 & 3.6 & 3.2 & 3.0 & 2.7 & 2.6 & 2.4 & 2.2 & 2.2 & 2.1 & 1.9 \\
\hline Kümilatif \% & 16.3 & 24.9 & 30.7 & 35.8 & 40.6 & 44.7 & 48.6 & 52.2 & 55.5 & 58.5 & 61.2 & 63.8 & 66.3 & 68.6 & 70.8 & 72.9 & 74.9 \\
\hline
\end{tabular}

Cizelge 6. Yerel Fasulye genotiplerine ait temel bileşen analizi

\begin{tabular}{|c|c|c|c|c|c|c|c|c|c|c|c|}
\hline Özellik & F1 & F2 & F3 & F4 & F5 & Özellik & F1 & F2 & F3 & F4 & F5 \\
\hline S-B & 0.94 & 0.03 & 0.02 & 0.12 & -0.03 & $\mathrm{~K}$ & 0.18 & -0.37 & 0.24 & 0.57 & 0.03 \\
\hline A & -0.16 & 0.35 & 0.12 & 0.17 & -0.16 & BKŞ & 0.15 & -0.12 & -0.12 & -0.09 & -0.16 \\
\hline SB & -0.75 & -0.29 & 0.10 & 0.11 & -0.01 & BBD & 0.93 & 0.04 & 0.03 & 0.10 & -0.02 \\
\hline SH & -0.90 & -0.07 & -0.07 & -0.12 & 0.08 & BUGU & 0.36 & -0.15 & 0.50 & -0.21 & 0.18 \\
\hline SG & -0.90 & -0.07 & -0.05 & -0.11 & 0.08 & BG & 0.06 & 0.40 & -0.45 & -0.20 & 0.33 \\
\hline SE & -0.76 & -0.23 & 0.07 & -0.03 & 0.05 & GK & -0.23 & 0.13 & -0.41 & 0.55 & 0.08 \\
\hline YR & 0.21 & -0.21 & 0.18 & 0.06 & -0.31 & BYY & 0.13 & -0.08 & -0.04 & 0.02 & 0.42 \\
\hline $\mathrm{P}$ & -0.04 & -0.12 & 0.15 & -0.16 & 0.02 & GOŞ & 0.31 & -0.13 & 0.41 & -0.50 & 0.03 \\
\hline OYB & -0.12 & 0.25 & -0.07 & -0.16 & -0.12 & GU & 0.47 & -0.16 & 0.36 & -0.27 & 0.13 \\
\hline OYŞ & -0.02 & -0.18 & 0.05 & -0.16 & 0.06 & BKŞ & -0.25 & -0.07 & -0.27 & 0.12 & 0.06 \\
\hline OYUŞ & 0.20 & 0.37 & -0.04 & -0.06 & 0.05 & BKİDBO & -0.28 & -0.06 & -0.27 & 0.24 & 0.09 \\
\hline BB & -0.10 & -0.14 & 0.06 & 0.07 & 0.04 & ÇKŞ & -0.04 & 0.20 & -0.03 & 0.18 & -0.02 \\
\hline BR & 0.18 & 0.04 & 0.10 & -0.24 & 0.04 & ÇGS & -0.47 & -0.38 & 0.19 & -0.28 & -0.21 \\
\hline $\mathrm{BŞ}$ & -0.10 & -0.29 & 0.36 & 0.16 & -0.06 & BBGS & -0.47 & -0.38 & 0.19 & -0.28 & -0.23 \\
\hline BYR & -0.15 & 0.66 & 0.08 & -0.38 & -0.16 & BDS & -0.14 & -0.14 & 0.05 & -0.08 & 0.10 \\
\hline $\mathrm{KR}$ & -0.16 & 0.65 & 0.07 & -0.38 & -0.18 & İBY & -0.16 & 0.24 & -0.39 & -0.05 & -0.29 \\
\hline $\mathrm{KAD}$ & -0.00 & 0.21 & 0.04 & 0.21 & -0.18 & BB & -0.72 & 0.12 & -0.10 & -0.15 & 0.12 \\
\hline BTÇBBY & 0.94 & 0.03 & 0.02 & 0.12 & -0.03 & BBS & -0.33 & -0.07 & 0.35 & 0.44 & -0.15 \\
\hline ÇU & -0.10 & 0.10 & 0.34 & -0.10 & 0.62 & YTA & 0.23 & 0.49 & -0.30 & -0.06 & 0.39 \\
\hline ÇSU & -0.21 & 0.09 & 0.30 & -0.08 & 0.49 & TV & -0.29 & 0.10 & 0.22 & 0.29 & -0.02 \\
\hline ÇB & -0.13 & 0.03 & 0.02 & -0.11 & 0.40 & OS & -0.48 & 0.06 & 0.13 & 0.14 & -0.03 \\
\hline İÇBS & -0.24 & 0.15 & -0.41 & -0.07 & -0.32 & KSV & -0.52 & -0.03 & 0.05 & 0.02 & 0.20 \\
\hline SÇTS & -0.21 & -0.09 & 0.02 & 0.04 & 0.43 & BTS & -0.31 & -0.09 & 0.15 & -0.06 & -0.38 \\
\hline BK & 0.00 & 0.14 & 0.19 & 0.18 & -0.11 & TD & -0.13 & 0.09 & -0.15 & 0.15 & 0.41 \\
\hline BÇR & -0.22 & 0.77 & 0.45 & 0.21 & -0.07 & Eigen değeri & 8.50 & 4.48 & 2.98 & 2.67 & 2.52 \\
\hline BK 2.RENK & -0.22 & 0.77 & 0.43 & 0.20 & -0.05 & Varyasyon (\%) & 16.35 & 8.62 & 5.72 & 5.13 & 4.84 \\
\hline 2.R.K. & -0.20 & 0.73 & 0.42 & 0.16 & -0.04 & Kümilatif (\%) & 16.35 & 24.97 & 30.70 & 35.83 & 40.67 \\
\hline OTKR & 0.02 & 0.16 & -0.16 & -0.44 & -0.22 & & & & & & \\
\hline
\end{tabular}


Çizelge 7. Batı Anadolu Bölgesi illerinden toplanılan yerel fasulye genotipleri, bitki boyu (cm) ve bitki başına tane verimleri ( $\mathrm{g}$ bitki $\left.{ }^{-1}\right)$

\begin{tabular}{|c|c|c|c|c|c|c|c|c|c|c|c|}
\hline $\begin{array}{c}\text { Genotip } \\
\text { No }\end{array}$ & $\begin{array}{l}\text { Bitki } \\
\text { boyu }\end{array}$ & $\begin{array}{c}\text { Tane } \\
\text { verimi }\end{array}$ & $\begin{array}{c}\text { Genotip } \\
\text { No }\end{array}$ & $\begin{array}{l}\text { Bitki } \\
\text { boyu }\end{array}$ & $\begin{array}{c}\text { Tane } \\
\text { verimi }\end{array}$ & $\begin{array}{c}\text { Genotip } \\
\text { No }\end{array}$ & $\begin{array}{l}\text { Bitki } \\
\text { boyu }\end{array}$ & $\begin{array}{c}\text { Tane } \\
\text { verimi }\end{array}$ & $\begin{array}{c}\text { Genotip } \\
\text { No }\end{array}$ & $\begin{array}{l}\text { Bitki } \\
\text { boyu }\end{array}$ & $\begin{array}{c}\text { Tane } \\
\text { verimi }\end{array}$ \\
\hline MGL-30 & 200.0 & 145.6 & MGL-25 & 190.0 & 35.6 & MGL-04 & 41.4 & 25.3 & KTH-30 & 72.7 & 17.3 \\
\hline MGL-38 & 180.0 & 101.7 & KTH-29 & 81.0 & 35.4 & IPT-10 & 220.0 & 25.2 & KTH-25 & 50.2 & 17.0 \\
\hline ANT-43 & 270.0 & 87.8 & BRD-14 & 120.0 & 35.3 & DZL-06 & 112.0 & 25.0 & MGL-36 & 100.0 & 16.8 \\
\hline MGL-26 & 210.0 & 81.9 & MNS-05 & 41.7 & 35.2 & ANT-47 & 199.0 & 24.8 & ANT-38 & 250.0 & 16.5 \\
\hline KTH-04 & 56.2 & 69.3 & MGL-13 & 41.0 & 35.0 & ANT-10 & 250.0 & 24.5 & ANT-07 & 177.5 & 16.3 \\
\hline ANT-29 & 164.0 & 68.8 & KTH-21 & 280.0 & 34.9 & ANT-15 & 215.0 & 24.0 & MGL-11 & 260.0 & 16.3 \\
\hline MGL-18 & 260.0 & 68.4 & ANT-50 & 103.0 & 34.8 & BRD-20 & 270.0 & 23.9 & MGL-33 & 270.0 & 16.3 \\
\hline ANT-24 & 194.0 & 67.8 & KTH-18 & 160.0 & 34.7 & DZL-02 & 126.3 & 23.5 & BRD-03 & 80.0 & 15.9 \\
\hline ANT-04 & 200.0 & 64.5 & AYD-11 & 193.0 & 33.5 & IPT-01 & 143.0 & 23.3 & КTH-32 & 270.0 & 15.7 \\
\hline KTH-03 & 181.0 & 62.9 & ANT-02 & 240.0 & 32.7 & MGL-01 & 240.0 & 23.3 & ANT-09 & 135.0 & 14.7 \\
\hline ANT-08 & 190.0 & 56.8 & ANT-48 & 45.0 & 32.6 & UŞK-01 & 42.8 & 23.2 & IPT-03 & 46.4 & 14.5 \\
\hline DZL-09 & 160.0 & 56.2 & BRD-29 & 210.0 & 32.5 & KTH-01 & 183.3 & 23.1 & MNS-07 & 46.3 & 14.0 \\
\hline AYD-15 & 190.0 & 55.8 & KTH-16 & 42.0 & 32.4 & BRD-07 & 153.0 & 23.1 & MGL-07 & 66.0 & 13.9 \\
\hline ANT-40 & 230.0 & 55.7 & ANT-21 & 82.0 & 32.0 & MGL-09 & 72.0 & 22.6 & KTH-05 & 280.0 & 13.8 \\
\hline MGL-27 & 270.0 & 55.5 & IZM-01 & 155.3 & 31.8 & BRD-18 & 142.0 & 22.5 & MGL-05 & 41.6 & 13.5 \\
\hline ANT-13 & 183.0 & 53.7 & IPT-09 & 290.0 & 31.6 & MNS-08 & 48.6 & 22.4 & BRD-02 & 42.6 & 13.5 \\
\hline KTH-02 & 183.0 & 53.6 & ANT-26 & 109.0 & 31.5 & ANT-22 & 129.6 & 22.3 & AYD-04 & 38.0 & 13.2 \\
\hline KTH-11 & 144.0 & 49.4 & AYD-07 & 200.0 & 31.3 & MGL-43 & 38.0 & 21.6 & AYD-02 & 39.8 & 13.2 \\
\hline MGL-24 & 260.0 & 49.0 & ANT-42 & 190.0 & 31.2 & BRD-25 & 96.7 & 21.1 & IZM-02 & 41.4 & 13.1 \\
\hline MGL-40 & 179.0 & 48.4 & MGL-19 & 250.0 & 31.0 & ANT-01 & 167.4 & 21.0 & MGL-39 & 170.0 & 13.1 \\
\hline ANT-25 & 207.0 & 47.6 & ANT-30 & 162.0 & 29.8 & MNS-03 & 233.7 & 20.9 & KTH-08 & 214.0 & 12.9 \\
\hline MGL-29 & 201.0 & 46.2 & MGL-08 & 340.0 & 29.6 & MGL-10 & 235.0 & 20.8 & MGL-32 & 245.0 & 12.9 \\
\hline ANT-14 & 192.0 & 44.7 & ANT-44 & 160.0 & 29.0 & DZL-03 & 50.7 & 20.7 & AYD-05 & 42.4 & 12.8 \\
\hline KTH-09 & 105.0 & 44.3 & DZL-05 & 160.0 & 28.8 & IPT-07 & 225.0 & 20.6 & MNS-01 & 95.7 & 12.1 \\
\hline MGL-21 & 120.0 & 43.8 & ANT-37 & 179.0 & 28.5 & IPT-05 & 210.3 & 20.5 & AYD-01 & 39.0 & 12.1 \\
\hline ANT-49 & 157.0 & 43.8 & MNS-04 & 200.0 & 28.1 & ANT-06 & 68.3 & 20.4 & MGL-16 & 180.0 & 11.2 \\
\hline IZM-04 & 245.0 & 43.1 & BRD-26 & 114.0 & 28.0 & KTH-28 & 50.0 & 20.3 & ANT-32 & 100.0 & 10.2 \\
\hline IPT-11 & 225.0 & 42.3 & KTH-24 & 53.8 & 27.9 & MNS-06 & 46.3 & 20.2 & ANT-05 & 59.6 & 10.1 \\
\hline AYD-16 & 197.0 & 42.0 & IPT-04 & 260.0 & 27.7 & MGL-15 & 77.0 & 19.9 & ANT-41 & 195.0 & 9.7 \\
\hline ANT-35 & 170.0 & 39.1 & KTH-06 & 40.2 & 27.4 & AYD-08 & 187.0 & 19.9 & ANT-36 & 153.0 & 9.4 \\
\hline KTH-31 & 50.0 & 38.5 & BRD-28 & 220.0 & 27.2 & ANT-39 & 230.0 & 19.6 & BRD-09 & 195.0 & 8.8 \\
\hline BRD-24 & 86.7 & 38.0 & ANT-45 & 183.3 & 26.3 & BRD-13 & 180.0 & 19.5 & MGL-17 & 230.0 & 8.3 \\
\hline MGL-22 & 165.0 & 38.0 & BRD-19 & 230.0 & 26.3 & KTH-27 & 49.2 & 19.3 & KTH-19 & 340.0 & 8.2 \\
\hline AYD-06 & 51.6 & 37.5 & BRD-16 & 103.0 & 26.1 & BRD-17 & 190.0 & 19.2 & BRD-15 & 320.0 & 7.3 \\
\hline KTH-26 & 160.0 & 37.4 & ANT-18 & 205.2 & 26.1 & MGL-14 & 160.0 & 19.2 & BRD-22 & 178.0 & 7.2 \\
\hline DZL-01 & 130.0 & 37.3 & AYD-03 & 49.3 & 26.0 & ANT-23 & 248.0 & 19.0 & KTH-17 & 156.0 & 7.1 \\
\hline MGL-20 & 160.0 & 36.8 & IPT-08 & 162.0 & 25.8 & KTH-33 & 60.0 & 18.8 & Ortalama & 158.7 & 30.0 \\
\hline PKS-01 & 340.0 & 36.3 & BRD-10 & 195.0 & 25.7 & AYD-09 & 190.3 & 18.0 & St. Hata & 6.32 & 1.51 \\
\hline IPT-02 & 227.0 & 36.1 & MGL-42 & 265.0 & 25.5 & KTH-15 & 78.3 & 17.4 & St. Sapma & 79.01 & 18.90 \\
\hline MGL-03 & 178.0 & 35.9 & AYD-14 & 281.0 & 25.4 & IPT-06 & 33.8 & 17.3 & $\mathrm{~N}$ & 156 & 156 \\
\hline
\end{tabular}

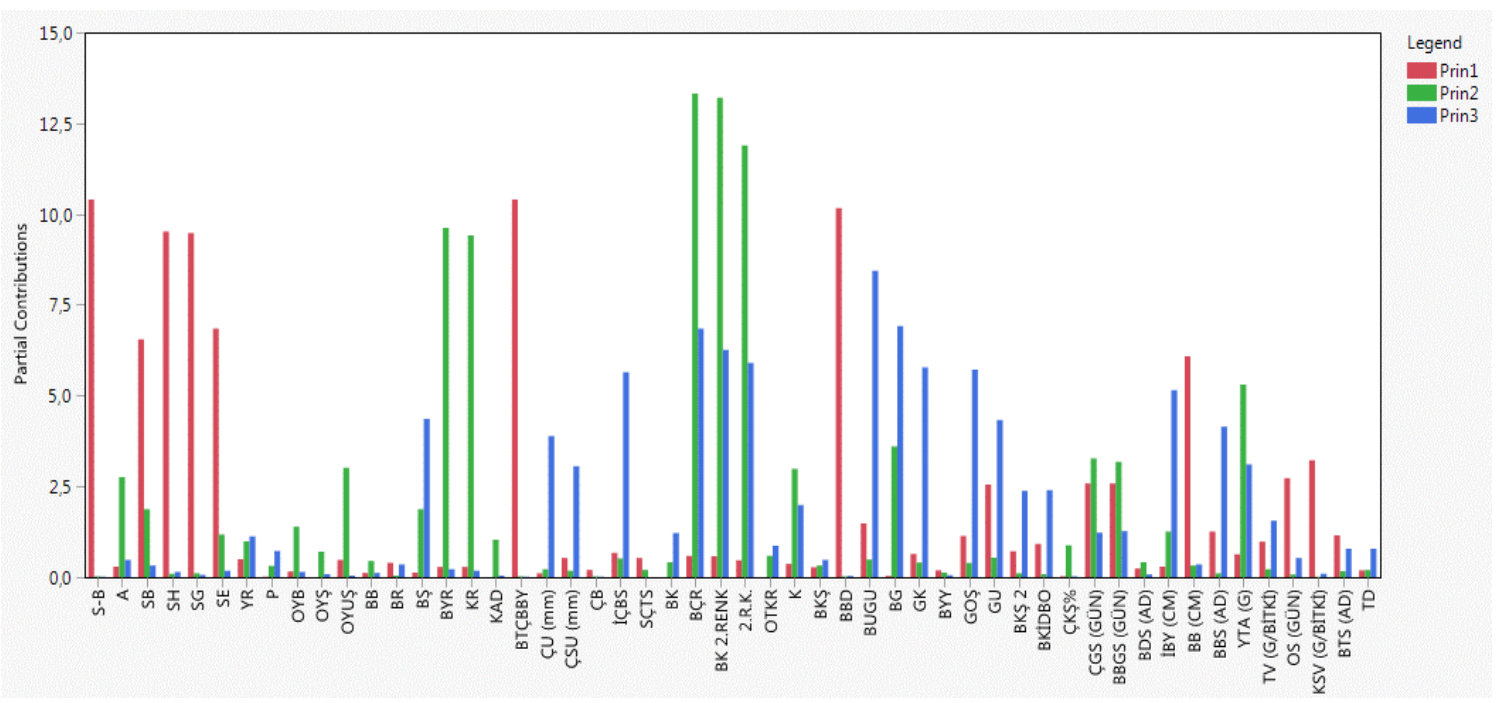

Şekil 3. Yerel fasulye genetik kaynaklarına ait incelen morfolojik özelliklerin varyasyona nisbi katkısı 


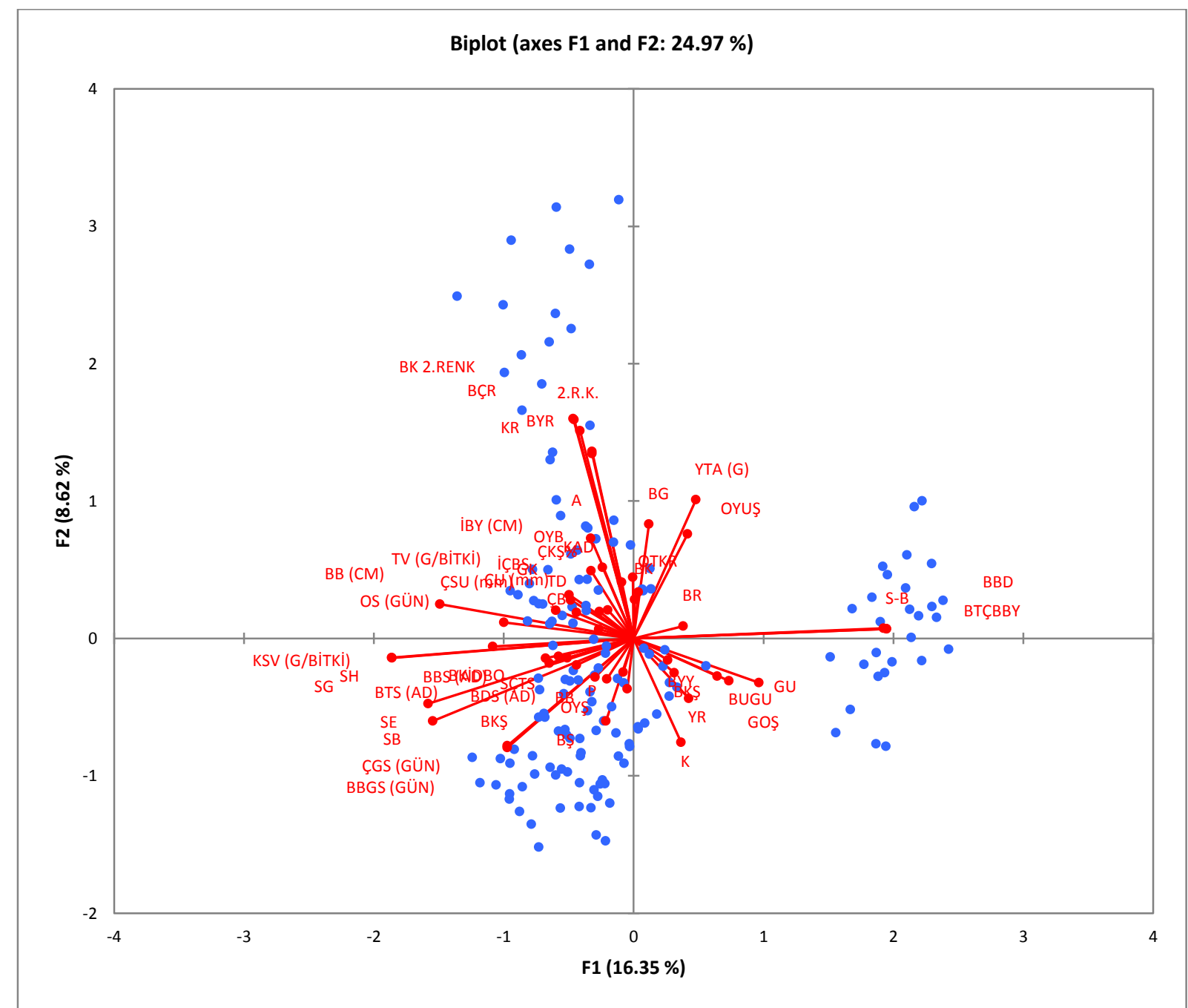

Şekil 4. Yerel fasulye genetik kaynaklarının morfolojik özelliklerine ait temel bileşen analizi biplot grafiği

Yerel fasulye genetik kaynaklarma ait morfolojik özelliklere ait veriler kullanılarak üretilen benzerlik takımyıldızı grafiği (dendogram) Şekil 5’te verilmiştir. Takımyıldızı grafiği UPGMA benzerlik dendogramına göre daha az yer tutmakta ve genotipler daha net olarak okunabilmektedir. Benzerlik takımyıldızı dendogramı ekotipleri önce iki ana gruba ayırmıştır (A ve B). Grafiğin sağ üst köşesinde UŞK-1 ile başlayan A kümesi iki alt kümeye ayrılmıştır. MGL-30 genotipi ile başlaya ve MGL-01 ile biten B kümesi ise önce B1 ve B2 şeklinde iki alt kümeye ayrılmış ve her bir alt küme iki alt-alt kümeye ayrılmıştır (Şekil 5). Benzerlik takımyıldızı grafiğine göre B.2.1.2 grubunda yer alan MGL-01, KTH-01, MNS-01, ANT-13, ANT-15, KTH-02 ve MGL-38 genotipleri A1 ve A2 grubunda yer alan UŞK-01, ANT-01, MGL-05, AYD-02, IPT-06, IPT03 ve IZM-02 genotipleri ile en yüksek farklılık (en uzak benzerlik) oranına sahip olmuşlardır (Şekil 5). A2 grubunda yer alan MGL-04, MGL-43, AYD-01, KTH25, KTH-27 ve KTH-28 genotipleri B1 grubuna giren MGL-30, AYD-16, AYD-15, MGL-09, ANT-43 ve MGL27 genotipleri ile en yüksek benzerlik oranına sahip olmuşlardır. Her bir alt grup içinde aynı grup içinde yer alan genotipler arasında benzerlik oranı yüksek bulunmaktadır.

156 yerel ekotipi içeren fasulye genetik kaynağı ile yürütülen bu çalışma Batı Anadolu Bölgesi’nin yerel fasulye genetik kaynakları açısından zengin bir çeşitliliğe sahip olduğunu göstermektedir. Üstün kalite özelliklerine ve yerel şartlara uzun süreli adaptasyon kapasitesine sahip yerel ekotiplerin toplanması, karakterizasyonu, ıslah programlarinda kullanarak yeni çeşitlerin ıslahı fasulye tarımının geliştirilmesi açısından oldukça önemlidir. Diğer ürünlerde görülen yoğun tarım uygulamalarının ve ticari çeşitlerin kullanımının yaygınlaşmasına rağmen fasulye tarımında yerel ekotiplerin kullanımı devam etmektedir. Önceki çalışmalar da bu bölgedeki çeşitliliğin varlığını teyit etmektedir (Çancı, 2016). Türkiye genel anlamda fasulye biyoçeşitliliği açısından zengin kabul edilmektedir. Batı Karadeniz Bölgesi (Sözen et al., 2012), Karadeniz Bölgesi (Pekşen and Gülümser (2005), Doğu Akdeniz Bölgesi (Anlarsal et al. 2000) ve Doğu Anadolu Bölgesi (Elkoca and Çınar, 2015) genetik kaynakları üzerinde yürütülen çalışmalar zengin yerel çeşitliliğe işaret etmektedir. 


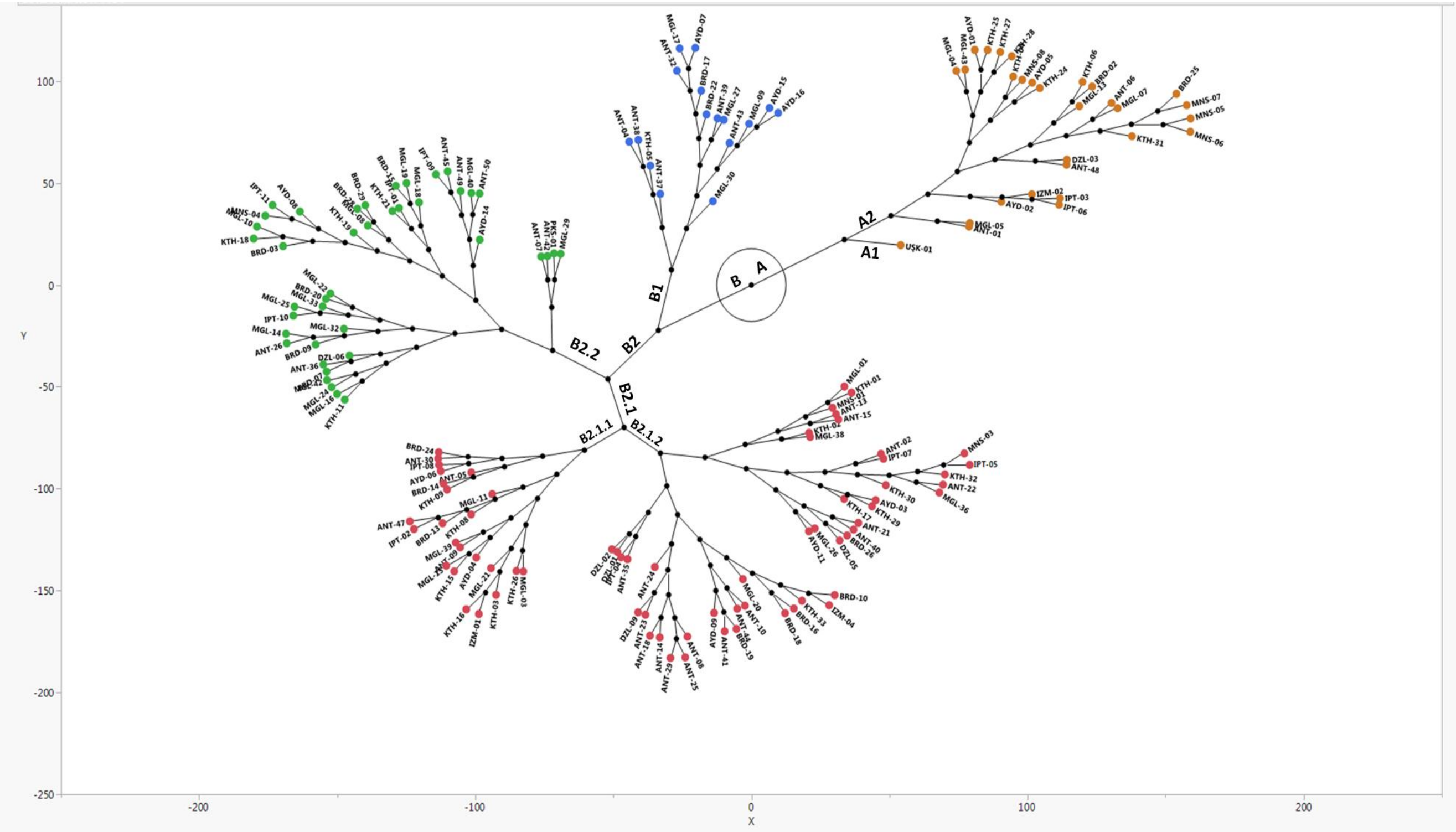

Şekil 5. Yerel fasulye genetik kaynaklarına ait benzerlik takımyıldızı grafiği 
Yüzylllardan beri hemen hemen her hanede devam eden fasulye üretimi, lezzet açısından üreticiler tarafindan yapılan seleksiyon ve yerel ekotiplere olan tüketici talebi yerel biyoçeşitliliğin oluşmasında önemli faktörler olarak ortaya çıkmaktadır. Bu makale, kapsaml tarama, toplama ve morfolojik karakterizasyon çalışması ile Batı Anadolu Bölgesi fasulye biyoçeşitliliğinden istifade edilebilmesi için gerekli alt yapıyı hazırlamaktadır. Benzerlik analizi sonucu üretilen genotiplere ait takım grafiği Batı Anadolu Bölgesi fasulye genetik kaynakları içinde morfolojik özellikler bakımından polimorfizim olduğunu göstermektedir. Doğu Anadolu Bölgesi'nden toplanılan fasulye genetik kaynakları üzerinde Simple Sequence Repeat (SSR) DNA belirteçleri ile yapılan analizlerde yüksek oranda polimorfizm tespit edilmiştir (Khaidizar et al., 2012). Benzer şekilde, ülkemiz fasulye genetik kaynakları ile yapılan çalışmalarda da, fasulyenin Türkiye orjinli olmamasına rağmen genotipler arasındaki genetik çeşitliliğin yüksek olduğu çeşitli araştırıcılar tarafından bildirilmiştir (Balkaya and Yanmaz, 2002; Sarikamis et al., 2009; Erdinc et al., 2017; Ekincialp ve Şensoy, 2018; Nadeem et al., 2018). Bölgesel, toprak ve iklim şartları, farklı yetiştirme teknikleri ve farklı tüketici talepleri doğrultunda seleksiyon gibi uygulamaları biyolojik çeşitliliğin oluşmasında etkili olduğu bildirilmiştir (Scarano et al., 2014). Yukarıdaki çalışmalar sonucunda tespit edilen polimorfizimden yararlanılarak yerel ve bölgesel amaçlar için ıslah çalışmaları yapılabilir. Bu çalışmada benzer şekilde tespit edilen polimorfizimden istifade edilerek (örn. MGL-01, KTH-01, MNS-01, ANT-13, ANT-15, KTH-02 ve MGL-38 genotipleri ile UŞK-01, ANT-01, MGL-05, AYD-02, IPT-06, IPT-03 ve IZM-02 genotipleri arasında görülen yüksek polimorfizim) melezleme ıslahı ile yeni çeşitler geliştirilebilir.

Fasulye genetik kaynakları içinde ölçülen morfolojik özellikler açısından çeşitliliğge en yüksek katkıyı bitki tipi, sarılma hızı ve ilk fide gelişmesine ait değerler vermiştir. Bunları çiçek rengi, bakla rengi ve bakla özellikleri takip etmiştir. Fide gelişme hızı ve bitki tipi fasulye üretiminde önemli özellikler olarak ortaya çıkmaktadır. Hızlı çimlenme, hızlı çıkış, hızlı fide gelişimi ve erken kanopi tesisi baklagil bitkilerinde avantaj olarak ortaya çıkmaktadır. Erken kanopi tesisi tarla şartlarında erken yaprak alanı tesisi, güneş ışığından daha fazla istifade edilmesi, evaporasyonun azaltılması, kuraklık stresinden kaçınma ve yabancı otlarla rekabet avantajlarını sağlamaktadır. Erkenci fasulye çeşitlerinin yüksek verim sağladığı bildirilmiştir (White and Izqueredo, 1991). Erken gelişme özelliğine sahip ANT-43, MGL18, DZL-09, MGL-24 ve PKS-01 ıslah çalışmalarında kullanılabilir. Çiçek ve bakla rengi ıslah çalışmalarında morfolojik markör olarak değerlendirilebilir.

Bu çalışmada bitki başına tohum verimi, bitki başına bakla verimi ile önemli ve pozitif korelasyon $(\mathrm{r}=0.545$, $\mathrm{P}<0.01$ ) göstermiştir. Fasulye üzerine yapılan Path analizi çalışmaları bitki başına bakla sayısı tohum verimi ile yüksek oranda ilişkili çıkmıştır (Toker and Cagirgan, 2004; Duzdemir, 2009; Petrova and Desheva, 2016). Yürütülen bu çalışmalarda bitki başına bakla sayısı ve tane ağırlığı en önemli verim unsurları olarak belirlenmiştir. Vigna mungo (L.) Hepper bitkisinde tohum verimi, bitki başına bakla sayısı, 100 tane ağırlığı, bitki boyu ve bakla uzunluğu ile ilişkili çıkmıştır (Parveen et al., 2011). İri daneli mercimek bitkisinde ise (Lens culinaris Medik.) bitki başına bakla sayısı en az etkili verim unsuru olarak belirlenmiştir (Çancı and Toker, 2006). Kulaz and Çiftçi (2012), bodur kuru fasulye (Phaseolus vulgaris L.) bitkisinde bu verim unsurlarının yanında toplam biyolojik veriminde de önemli olduğunu bildirmiştir. Taze fasulye verimi üzerine bakla sayısının önemli etkisi olduğu bildirilmiştir (Prakash et al., 2015). Bu çalışmada bitki boyu (cm), olgunlaşma gün sayısı (OG), çiçek sapı uzunluğu (ÇSU), çiçek boyutu (ÇB), ilk çiçek boğum sayısı (İÇBS), orta yaprakçığın büyüklüğü (OYB) ve ilk bakla yüksekliği (IBY) özellikleri tane verimi ile aynı yönde ve en dar açıya sahip vektör değerlerine sahip özellikler olarak ortaya çıkmıştır. Bakla sayısı yanında tane veriminin yukarıdaki özelliklerle ilişkisinin daha detaylı incelenmesi gerekir. Ancak, bütün bahsedilen denemelerden elde edilen sonuçlarla birlikte değerlendirildiğinde bitki başına bakla sayısının önemli bir seleksiyon kriteri olarak kullanılabileceği görülmektedir. Bitki başına tane verimi ortalama $33.53 \mathrm{~g}(\mathrm{Std}$. sapma $=11.73)$ olup minimum $7.1 \mathrm{~g}$ ile $145.6 \mathrm{~g}$ arasında $6.38 \mathrm{katı}$ değişim göstermiştir. Diğer çalışmalarda (Anlarsal ve ark., 2000) bitki başına tohum verimi bodur tiplerde $7.3 \mathrm{~g}$ ile $14.3 \mathrm{~g}$ arasında, sarılıcı tiplerde $3.6 \mathrm{~g}$ ile $9.4 \mathrm{~g}$ arasında, Çiftçi ve ark. (2009) ise 9.59-119.28 g arasında değiş̧tiği bildirilmiştir. Bu çalışmada değişim oranı daha yüksek bulunmuştur. Özellikle yüksek verimli MGL-30 (145.6 g), MGL-38 (101.7 g), ANT-43 (87.8 g) ve MGL-26 (81.9 g) ıslah çalışmalında ileri yol materyali olarak kullanılabilir. $\mathrm{Bu}$ çalışmada morfolojik ve fenolojik özellikler açısından tespit edilen değerlerdeki değişim, önceki bazı çalışmalardan (Sözen ve ark., 2012; Pekşen ve Gülümser, 2005; Elkoca ve Çınar, 2015; Çancı, 2016) daha yüksek bulunmuştur. Bu çalışmada tespit edilen bitki boyu değerleri $(33.8-340.0 \mathrm{~cm}$, ort.158.8 cm), Elkoca and Çınar (2015) (37.7-50.5 cm ), Pekşen ve Gülümser (2005) (17.7- $103 \mathrm{~cm})$ ve Sözen ve ark. (2012) (39.2$262.0 \mathrm{~cm}$ ) tarafindan rapor edilen değerlerden daha yüksek bulunmuştur. Belirtilen farklılık diğer fenolojik ve morfolojik özelliklerde de görülmektedir. $\mathrm{Bu}$ farklılık, üzerinde çalışılan genetik kaynakların toplama alanlarındaki coğrafi çeşitlilikle ilgili olabilir. Bu çalışmada Akdeniz Bölgesi illeri yanında Batı ve Kuzey Ege Bölgesi illeri gibi farklı iklim ve coğrafya alanlarından toplama yapılmıştır. Kütahya gibi 
Marmara, Ege ve İç Anadolu bölgelerinin birleşme alanında yer alan illerin biyolojik çeşitlilik açısından daha zengin olduğu bilinmektedir.

\section{SONUÇ}

Batı Anadolu Bölgesi’nde çok farklı iklim ve coğrafik özelliklere sahip 10 ilinden toplanılan 156 yerel fasulye ekotipi üzerinde tarla şartlarında yapılan gözlemlerde fenolojik ve morfolojik özellikler açısından çok zengin bir varyasyon belirlenmiştir. Yerel ekotiplerdeki bu varyasyondan istifade ederek üstün verimli ve adaptasyon yeteneği yüksek fasulye çeşitleri geliştirilebilir. Tespit edilen morfolojik özellikler seleksiyon ve melezleme islahinda markör olarak kullanılabilir. Yüksek tane verimine sahip sarılice MGL-30, MGL-38, ANT-43 ve MGL-26 ve bodur KTH-04, KTH-31, BRD-24 ve AYD-06 ekotipleri ileri ıslah çalışmalarında kullanılabilir. Morfolojik özellikler açısından en uzak gruplarda yer alan MGL01, KTH-01, MNS-01 ve ANT-13 ile UŞK-01, ANT-01, MGL-05 ve AYD-02 ekotipleri kullanılarak melezleme ıslahı ile yeni çeşitler geliştirilebilir.

\section{TEŞEKKÜR}

Bu çalışma Türkiye Bilimsel ve Teknolojik Araştırma Kurumu (TUBITAK) tarafindan desteklenmiştir (Proje no. 115R042).

\section{KAYNAKLAR}

Anlarsal AE, Yücel C, Özveren D 2000. The Determination of Seed Yield and Yield Components in Some Bean (Ph. vulgaris) Cultivars and Correlations Between These Characters Under the Cukurova Conditions. Turkish Journal of Agriculture and Forestry, 24: 19-29 (in Turkish with English summary).

Anonim 2018a. Food and Agricultural Organization. http://www.fao.org/faostat/en/\#data/QC. (Erişim tarihi: 17 Ocak 2018).

Anonim 2018b. Turkish Statistical Institute, Ankara, Turkey.

http://www.turksat.gov.tr/PreTablo.do?alt_id=1001 (Access date: 18 Ocak 2018).

Aquino-Bolaños EN, García-Díaz YD, Chavez-Servia JL, Carrillo-Rodríguez JC, Vera-Guzmán AM, Heredia-García E 2016. Anthocyanin, polyphenol, and flavonoid contents and antioxidant activity in Mexican common bean (Phaseolus vulgaris L.) landraces. Emirates Journal of Food and Agriculture, 28: 581-588.

Balkaya A, Yanmaz R 2002. Morphological properties of cultivar nominates selected Black Sea Region bean populations and identification by protein markers. Ankara University Journal of Agricultural Sciences, 9. 182-188.

Bitocchi E, Bellucci E, Giardini A, Rau D, Rodriguez M, Biagetti E, Santilocchi R, Spagnoletti Zeuli P, Gioia T, Logozzo G, Attene G, Nanni L, Papa R 2013. Molecular analysis of the parallel domestication of the common bean (Phaseolus vulgaris) in Mesoamerica and the Andes. New Phytologist, 197: 300-313.

Blair MW, Galeano CH, Tovar E, Muñoz Torres MC, Castrillón AV, Beebe SE, Rao IM 2012. Development of a Mesoamerican intra-genepool genetic map for quantitative trait loci detection in a drought tolerant $\times$ susceptible common bean (Phaseolus vulgaris L.) cross. Molecular Breeding, 29(1): 71-88.

Cancı H, Toker C 2006. Evaluation of selection criteria in large-seeded Lentil (Lens culinaris Medik.) Genotypes Using Phenotyping Correlations, Path and Factor Analyses. Turkish Journal of Field Crops, 11:19-27.

Çancl H 2016. Determination to Phenologic, Morphologic and Agronomic Characters of Bean (Phaseolus spp.) Mini- Core Collection in Antalya Conditions. Research Journal of Agricultural Sciences, 9: 26-32 (in Turkish with English summary).

Çiftçi V, Şensoy S, Türkmen Ö 2009. Van-Gevaş'ta Yaygin Olarak Yetiştirilen Yalancı Dermason Fasulye Populasyonunun Seleksiyon Yöntemiyle Islahı, TOVAG- 1060346 Nolu Proje Sonuç Raporu.

De La Fuente María, López-Pedrouso M, Alonso J, Santalla M, De Ron A.M, Gonzalo A, Zapata C 2012. In-depth characterization of the phaseolin protein diversity of common bean (Phaseolus vulgaris L.) based on two-dimensional electrophoresis and mass spectrometry. Food Technology and Biotechnology, 50(3): 315-325.

Duzdemir O 2009. Using Path Coefficient Analysis to Determine the Relationship between Yield and Yield Components of Dry Bean (Phaseolus vulgaris L.). Journal of Applied Biological Sciences, 3: 45-49.

Ekincialp A, SSensoy S 2018. Determination of Genetic Diversity Using Phenotypic and Molecular Methods among Bean Genotypes (Phaseolus vulgaris L.) in Lake Van Basin. Turkish Journal of AgricultureFood Science and Technology, 6(7): 893-902.

Elkoca E, Çnar T 2015. The adaptation, agronomical and quality characteristics of some dry bean (Phaseolus vulgaris L.) cultivars and lines under Erzurum ecological conditions. Anadolu Journal of Agricultural Science, 30: 141- 153 (in Turkish with English summary).

Elkoca E, Haliloglu K, Kantar F, Eken C, Donmez F, Aydin M 2010. Genetic diversity of common beans (Phaseolus vulgaris L.) grown in the northeast region of Turkey based on morphological traits. 5th International Food Legumes Research Conference (IFLRC V) \& 7th European Conference on Grain Legumes (AEP VII), Legumes for Global Health, Legume Crops and Products for Food, Feed and Environmental Benefits, scientific books, (pp. 36), 26-30 April, 2010, Antalya, Turkey.

Erdinc C, Turkmen O, Dasgan HY, Sensoy S 2017. 
Phenotypic and molecular genetic diversity among some Turkish bean genotypes. JAPS: Journal of Animal \& Plant Sciences, 27(6):1963-1973.

Khaidizar MI, Haliloglu K, Elkoca E, Aydin M, Kantar F 2012. Genetic diversity of common bean (Phaseolus vulgaris L.) landraces grown in northeast Anatolia of Turkey assessed with simple sequence repeat markers. Turkish Journal of Field Crops, 17(2): 145-150.

Kulaz H, Çiftçi V 2012. Relationships among yield components and selection criteria for seed yield improvement in bush bean (Phaseolus vulgaris L.). Journal of Agricultural Science, 18: 257-262.

Kwak M, Gepts P 2009. Structure of genetic diversity in the two major gene pools of common bean (Phaseolus vulgaris L., Fabaceae). Theoretical and Applied Genetics, 118(5): 979-992

Nadeem MA, Habyarimana E, Çiftçi V, Nawaz MA, Karaköy T, Comertpay G, Ercişli S 2018. Characterization of genetic diversity in Turkish common bean gene pool using phenotypic and whole-genome DArTseq-generated silicoDArT marker information. PloS one, 13(10), e0205363.

Parveen SI, Sekhar MR, Reddy DM, Sudhakar P 2011. Correlation and path coefficient analysis for yield and yield components in blackgram (Vigna mungo (L.) Hepper). International Applied Biology and Pharmaceutical Technology, 2: 619-625.

Prakash J, Ram RB, Meena ML 2015. Genetic variation and characters interrelationship studies for quantitative and qualitative traits in french bean (Phaseolus vulgaris L.) under Lucknow conditions. Legume Research, 38: 425-433.

Pekşen E, Gülümser A 2005. Relationships between seed yield and yield components and path analysis in some common bean (Phaseolus vulgaris L.) Genotypes. The Journal of Agricultural Faculty of
Ondokuz Mayıs University, 20: 82-87 (in Turkish with English summary).

Petrova SD, Desheva GN 2016. Path coefficient and correlation analyses of quantitative characters in Chickpea (Cicer arietinum). Phytologia Balcanica, 22: 243-246.

Sarıkamış G, Yaşar F, Bakır M, Kazan K, Ergül A 2009. Genetic characterization of green bean (Phaseolus vulgaris) genotypes from eastern Turkey. Genetics and Molecular Research, 8(3): 880-887.

Scarano D, Rubio F, Ruiz JJ, Rao R, Corrado G 2014. Morphological and genetic diversity among and within common bean (Phaseolus vulgaris L.) landraces from the Campania region (Southern Italy). Scientia Horticulturae, 180: 72-78.

Scarano D, Rao R, Masi P, Corrado G 2015. SSR fingerprint reveals mislabeling in commercial processed tomato products. Food Control, 51: 397401.

Singh RJ, Chung GH, Nelson RL 2007. Landmark research in legumes. Genome, 50: 525-537.

Sözen Ö, Özçelik H, Bozoğlu H 2012. Determination of Biodiversity of Collected Beans (Phaseolus vulgaris L.) Populations in Western Black Sea Region, Turkey. Research Journal of Agricultural Sciences, 5: 59-63 (in Turkish with English summary).

Toker C, Cagirgan MI 2004. The use of phenotypic correlations and factor analysis in determining characters for grain yield selection in chickpea (Cicer arietinum L.). Hereditas, 140: 226-228.

White JW, Izquierdo J 1991. Physiology of yield potential and stress tolerance. In: A. van Schoonhoven \& O. Voysest (Eds.), Common Beans. Research for Cop Improvement, pp. 287-382. CAB Int CIAT, Colombia. 